\title{
Determination of Glyphosate in human urine from farmers in Mato Grosso-BR
}

\author{
Karolyne Gramlich de Melo' \\ Siomara Regina Ferreira Jacobucci \\ Célia Regina Garlipp 3 \\ Ângelo Zanaga Trape ${ }^{4}$ \\ Paulo César Pires Rosa ${ }^{5}$
}

\section{ABSTRACT}

This study was conducted based on the evaluation of glyphosate levels present in rural workers in the region of Nova Mutum-MT. We analyzed 90 urine samples from farmers between 2017 and 2018 . The samples were analyzed based on the development of the high-performance liquid chromatography (HPLC-FL) method. The results showed that $12 \%$ of the farmers presented glyphosate levels, but that the highest concentration determined by the method used was not above the limits allowed by Brazilian regulators. The HPLC-FL method proved to be practical and accurate for the determination of glyphosate in urine samples with limits of detection and quantification of 0.34 and $1.15 \mathrm{ng} / \mathrm{mL}$, respectively. These data show the importance of evaluating the occupational exposure of farmers to adopt strategies for the biomonitoring of this region, considering that casual exposures to pesticides can generate health risks, as well as cases of intoxication.

Keywords: Glyphosate; pesticides; occupational exposure; rural workers.

\section{INTRODUCTION}

Pesticides are products synthesized from physical, chemical or biological processes, being mainly used in agricultural sectors in order to change the composition of the fauna or flora and preserve them from harmful agents. Because it is a global concern, these substances have been the focus of several studies, not only by the impacts upon the health of human beings, but also by the concern with environment contamination, whether in water, soil, or other means. In addition to environmental and food contamination, pesticides can affect the health of different populations not only restricted to rural workers, but also to their families and individuals residing in the vicinity of the crop regions [1].

Studies conducted to evaluate occupational exposure to pesticides in rural regions in Brazil have shown contamination rates in farmers ranging from 3 to $23 \%$ [2] [3]. In Mato Grosso, a Brazilian state where pesticides are used, a study was conducted on the rate of intoxications

\footnotetext{
$1 *$ Department of Pharmacology, Faculty of Medical Sciences, University of Campinas (UNICAMP), Brazil.

${ }^{2}$ Laboratory of Toxicology Labtox, Faculty of Medical Sciences, University of Campinas (UNICAMP), Brazil.

${ }^{3}$ Department of Pathology, Faculty of Medical Sciences, University of Campinas (UNICAMP), Brazil.

${ }^{4}$ Laboratory of Toxicology Labtox, Faculty of Medical Sciences, University of Campinas (UNICAMP), Brazil.

${ }^{5}$ 1Department of Pharmacy, Faculty of Pharmaceuticals Sciences, University of Campinas (UNICAMP), Brazil. paulocpr@unicamp.br

Address for correspondence: Paulo Cesar Pires Rosa, phD. Laboratory of Pharmaceutical Supplies and Medicines. Faculty of Pharmaceutical Sciences

University of Campinas (UNICAMP), 13083-881. Campinas (São Paulo), Brazil. Tel:+55-19-3521-9585. E-mail: paulocpr@unicamp.br
}

Como citar este artigo / How to cite this article

Melo KG, Jacobucci SRF, Garlipp CR, Trape AZ, Rosa PCP. Determination of Glyphosate in human urine from farmers in Mato Grosso-BR. InterAm J Med Health 2020;3:e202003061. 
caused by these agents. The authors evaluated 141 municipalities between 2012 and 2014. The results showed there were about $13.2 \%$ cases of acute intoxications caused by pesticides in this period [4].

By May 2019, the Ministry of Agriculture had already approved 169 new pesticides, representing a rate 14\% higher than the previous year [5]. These products are produced from active principles that are already approved by the country. However, their toxicity is not known since they present formulations different from those already registered [6]. Studies affirm there is no guarantee of safety for these new formulations, as the toxicity of the separate additional agents is different from the complete formulation [7]. In addition, these adjuvants are often more toxic than the active ingredient itself. In the case of Roundup $®$, for example, with the active ingredient being glyphosate, this formulation presents a tensioactive agent called polyoxyethylenenamine (POEA), which has an estimated toxicity of three times higher compared with glyphosate [8]. Several studies have indicated this composition as a possible endocrine disrupter. Although the mechanisms for this action were not completely elucidated, the authors concluded that the formulation of the Roundup $®$ presented higher toxicity than the active product alone [9] [10]. Thus, other studies are necessary to evaluate whether this toxicity is caused by the main commercial component (glyphosate) or by the interactions among the other components present in the formulation.

Information about the pesticide class and the active ingredient used is of great relevance in order to evaluate the effects of these components on human health. In addition, some studies allow us to affirm that most of the cases of intoxications occurring in Brazil are due to the lack of public policies for the correct use of pesticides; low level of schooling of farmers and little understanding of the use of these agents during a continuous and longterm exposure. Moreover, the country lacks biological monitoring to evaluate the exposure levels of pesticides in rural workers [11].
Given this context, we can affirm the Brazilian official data do not show the country's reality about pesticide intoxication [11]. Therefore, it became essential to evaluate the populations exposed to pesticides to measure the levels of contamination present in the exposed individuals; provide for diagnoses of changes in their health status and propose stricter public safety measures to control this exposure.

\section{Glyphosate}

Known chemically as $\mathrm{N}$-(phosophomethyl)glycine, the molecular formula glyphosate C3H8NO5P is the most popular and used herbicide in the world. It has a record in more than 120 countries, representing $60 \%$ of the world market for non-selective herbicides. In addition, liquid, solid or granular commercial formulations present between $1 \%$ and $80 \%$ of the active ingredient, with the lowest percentage for domestic use [12].

Glyphosate is the most widely used active ingredient in Brazil, with 173,150.75 tonnes sold in 2017. It belongs to the class of herbicides and had its emergence in 1974 by Monsanto with the trade name Roundup $®$ [13]. In 1978, it was sold for the first time in Brazil by importation and, only in 1984, it began to be produced in the country [14]. It is a non-selective, systemic, post-emergent agent and has high efficiency in weed elimination [12].

Its wide use can be justified, as this herbicide has generated one of the greatest advances in agriculture from the environmental perspective. This is because, in the past, the biggest problem in crop regions was the erosion caused by the techniques of ploughing and harrowing, used for combating weeds. With the emergence of glyphosate, it was possible to extinguish these techniques, which increased the use of no-tillage and drastically reduced the occurrence of erosions in the crop areas [15]. In Figure 1, we can observe the distribution of the amount of glyphosate marketed in Brazil between 2009 and 2017 [13]. 


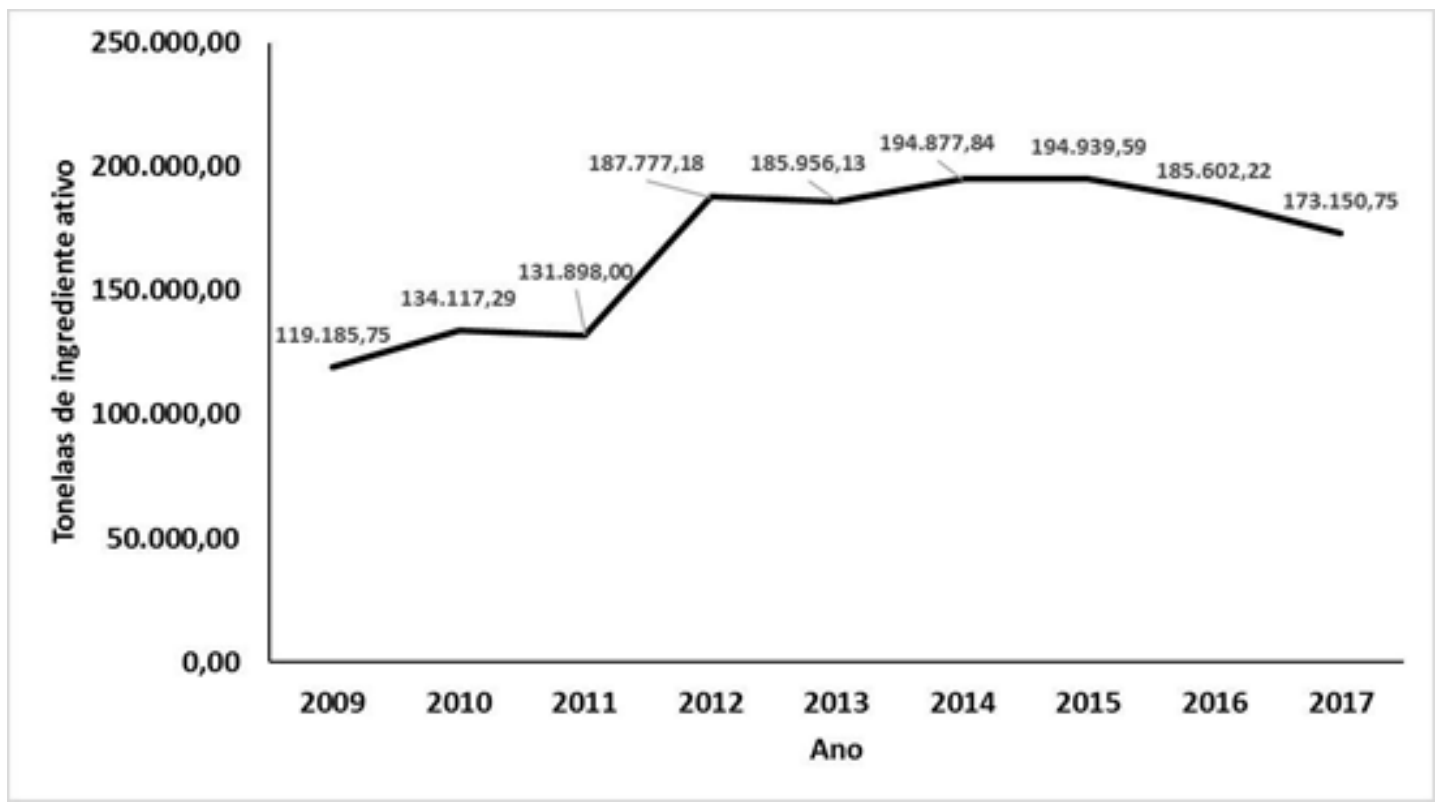

Figure 1. Gramlich et al. 2019

A study on the distribution of pesticide use in Brazil by Pignati, 2017, showed that, between 2012 and 2016, glyphosate was among the 20 most used active ingredients in Brazil. In addition, the authors reported that of the many cultures in which this herbicide is applied, the main ones are soybean, sugarcane and maize. The authors of the study also showed that transgenic monoculture can increase the use of pesticides, since these crops are generally tolerant to glyphosate and, therefore, cause the emergence of more resistant pests, increasing thus the use of this herbicide [4].

Currently, glyphosate has been undergoing a toxicological revaluation due to suspicions of presenting possible mutagenic, teratogenic and carcinogenic characteristics. In this context, ANVISA reassessed the parameters for the risk assessment of glyphosate by establishing new levels for: Acceptable daily intake (ADI) $=0.5 \mathrm{mg} / \mathrm{kg} / \mathrm{day} ;$ acute reference dose $(A R f D)=0.5 \mathrm{mg} /$ $\mathrm{Kg} /$ day and acceptable operator exposure level (AOEL) $=$ $0.1 \mathrm{mg} / \mathrm{Kg} /$ day [13]. In the United States, regulatory bodies consider an ADI of $1.75 \mathrm{mg} / \mathrm{kg} /$ day [16]. In the European Union, the limit is $0.3 \mathrm{mg} / \mathrm{kg} /$ day [17].

This degree of exposure was defined based on studies that are usually sponsored by the companies that sell the herbicide. However, in addition to much of the studies being outdated, they also deal only with cases of acute intoxication, not being adequate to evaluate low exposure levels. Thus, the current parameters that evaluate the levels of daily intake of pesticides in foods do not reflect the total reality [18].

However, researchers from different parts of the world diverge on the ADI values stipulated by the regulatory bodies. Scientists point out that this dose should be $0.025 \mathrm{mg} / \mathrm{kg} / \mathrm{day}$, that is, 12 times lower than that defined by EFSA and 70 times lower than that allowed in the United States [17]. In addition, the daily intake limit established by ANVISA of $0.042 \mathrm{mg} / \mathrm{kg} /$ day does not include tests with glyphosate for pesticide residues in food [13]. In addition, the regulatory bodies established these limits only for the isolated active principle, that is, without the presence of adjuvant agents [19-23].

Findings in the literature affirm that the complete formulations of glyphosate, that is, those that are marketed, usually present higher toxicity than glyphosate alone, besides increasing the toxicity of this herbicide when in the presence of the other components [24]. Also, these compositions are rarely tested for their longterm toxic effects. In short, we can observe that there is a limitation in the regulatory process regarding the toxicity levels of pesticides in a general context [25] [26].

Accidental exposures are commonly cases of low severity. For adult individuals who ingested doses greater than $0.5 \mathrm{mg} / \mathrm{kg}$, a hospital evaluation and monitoring is recommended. Lethal cases in adult individuals occur with the ingestion of $200 \mathrm{~mL}$ of glyphosate solution with 30 to $70 \mathrm{~g}$ of this active ingredient. Generally, it has 
been reported that in cases of acute intoxication with glyphosate, individuals may present symptoms such as: Renal and hepatic insufficiency, arrhythmia, pulmonary edema, hyperkalemia, respiratory distress, mouth and throat pain, and burning sensation in the stomach, among others [26].

The toxicity mechanism of glyphosate in the human organism is not yet completely elucidated, but researchers believe that it may interfere with oxidative phosphorylation. Moreover, the liquid formulations are more dangerous than the other ones, since it is assumed that the adjuvant components present in the formulations of glyphosate may interfere with the mitochondrial function, which may cause pulmonary edema [27] [28] [29].

Due to the facts mentioned, it is necessary to monitor biological and reliable biomarkers to ensure safety regarding the exposure of humans to pesticides.

\section{Sample collection region}

The state of Mato Grosso is the Brazilian state with the highest soybean production. According to Brasil, 2010, between 2009 and 2010, this state produced almost $30 \%$ of the Brazilian production. In relation to the predominance of agricultural crops in this region, there are: soybean $(63 \%)$, maize $(25 \%)$, cotton $(4 \%)$, sugarcane $(2 \%)$, beans $(2 \%)$, rice $(1 \%)$, and sunflower $(1 \%)[30]$.

Among the 10 municipalities in the state of Mato Grosso where pesticides are used, Nova Mutum-MT is ranked in the fifth position with 9.0 million liters. The first place, Sorriso-MT, produced 14.6 million liters. Among the various agrochemicals used in these regions, glyphosate occupies the first position [31].

The profile of farmers, evaluated the characteristics of family farming in Brazil, as well as the farmers' origin, sex, schooling and training, age and experience in rural activity. His studies showed that most farmers are men, representing almost $80 \%$ of the total rural farmers [32] [33]. Regarding the level of schooling and training, about $75 \%$ had some elementary school and only $0.2 \%$ had college degree. Other studies have already shown the direct relationship between the level of schooling of rural workers with the protective effect for pesticide intoxication during high chemical exposure. The age, which varies around 40 years, and the time of experience showed no relation with the cases of intoxication [34].
Therefore, it is important to analyze the relationship between occupational exposure and socioeconomic data of rural workers, as they may be directly related to cases of pesticide intoxication.

\section{MATERIALS AND METHODS}

\section{Study design}

It is a study on the impacts of exposure and direct contact in the long term, that is, more than 1 year, of glyphosate to the rural worker in the region of Nova Mutum-MT, based on a methodology developed and validated by the authors themselves. This study is relevant since there are currently no other public laboratories in Brazil with a methodology developed and validated for this same herbicide in biological samples.

\section{Description of the study}

An analytical methodology was developed for the determination of glyphosate in human urine samples by high-performance liquid chromatography with fluorescence detection (HPLC-FL).

For this study, urine samples were collected from December 2016 to December 2017, with 30 farmers with exposure to the glyphosate pesticide. The samples were originated from the Nova Mutum region - Mato Grosso (MT) and approved by the Research Ethics Committee (CEP) of the School of Medical Sciences of the University of Campinas - SP.

All participants signed an informed consent form of the use of their samples for scientific purposes. The farmers participating in the study were selected based on direct contact with the said pesticide, that is, all participants in direct contact with glyphosate were inserted in the study. Moreover, there was no restriction for the participants (exposure time, sex, age, etc.).

Table 1 shows the information on the sample collection, age and exposure time of farmers. The samples were classified into three types: pre, high and post, where: Pre means before exposure of individuals to pesticides; High means the period during exposure and direct contact to pesticides; Post informs the period after exposure. Thus, 30 samples were collected for each exposure period, totaling 90 samples analyzed. 


\section{Parameters}

Number of samples collected

Age of farmers (years)

Mean

Range

Exposure time (months)

Mean
90

$20-50$

30.7

Table 1. Data of the study participants.

\section{Sample preparation}

The stock solutions of the glyphosate pesticide were prepared by the dissolution in water of $10 \mathrm{mg}$ of standard dose for a final volume of $10 \mathrm{~mL}$. We prepared $100 \mathrm{~mL}$ of a working solution of concentration $6.0 \mathrm{ng} / \mathrm{mL}$, containing the glyphosate pesticide.

The samples were removed from the freezer, allowing them to reach the room temperature of their homogenization. We pipetted $2 \mathrm{~mL}$ of urine and added $0.4 \mathrm{~mL}$ of the standard working solution and $0.6 \mathrm{~mL}$ of acetonitrile. The samples were centrifuged at 3000rpm for 10 minutes and passed in SPE C18 pre-conditioned cartridges with $2 \mathrm{~mL}$ of acidified methanol with $100 \mu \mathrm{L}$ of $0.1 \%$ formic acid (solution of deaerated methanol) and eluted with $3 \mathrm{~mL}$ of acetonitrile. The calibration curve was evaluated from 1.15 to $120.00 \mathrm{ng} / \mathrm{mL}$. All calibration points were reproduced in triplicate. For the derivatization reaction, a concentration of $1.6 \mu \mathrm{L} / \mathrm{mL}$ of $\mathrm{Fmoc}-\mathrm{Cl}$ and $500 \mu \mathrm{L}$ of borate buffer solution $\mathrm{pH} 9$ for each $1 \mathrm{~mL}$ of sample was added, so that the proportion of glyphosate and Fmoc-Cl was 1:4. The derivatization reaction was performed in an ultrasonic cleaner for 15 minutes at room temperature.

\section{Equipment}

The samples were analyzed in the ultra-efficient liquid chromatography system LC-6AD, Waters, composed of automatic injector model 717plus Autosampler; fluorescence detector 2475; and data acquisition system by the Waters EmpowerTM 3 software (G. Bookham,
United Kingdom). The chromatographic Kromasil C18 column (150mm x $4.6 \mathrm{~mm}$ ) Thermo Electron Corporation was used. SPE Waters OASIS cartridges, HLB Catridge, 30 $\mu \mathrm{m}$ Particle Size (Massachusetts, USA); Mobile phase flow: $1.0 \mathrm{~mL} / \mathrm{min}$; Injection Volume: $20 \mu \mathrm{L}$; Automatic sampler temperature: $24^{\circ} \mathrm{C}$; Detector: wavelength emission and excitation: $263 \mathrm{~nm}$ and $317 \mathrm{~nm}$, respectively.

\section{RESULTS}

The validation was performed following the parameters recommended by the National Sanitary Surveillance Agency (ANVISA) through the Collegiate Board Resolution (RDC) No. 27, 2012.

For the LOD and LOQ, we performed injections in glyphosate six times in matrix at concentrations between $1.15 \mathrm{ng} / \mathrm{mL}$ and $120 \mathrm{ng} / \mathrm{mL}$ to obtain the calibration curve through which the theoretical LOD and LOQ was calculated, based on the residual standard deviation of the regression curve and on the slope of the calibration curve. The coefficient of determination was higher than 0.99 . All the calibration curve points were within $20 \%$ of the theoretical value. This method showed a limit of detection of $0.34 \mathrm{ng} / \mathrm{mL}$ and limit of quantification of $1.15 \mathrm{ng} /$ $\mathrm{mL}$. The lowest level determined $(1.15 \mathrm{ng} / \mathrm{mL})$ showed optimum accuracy and precision.

According to the results obtained, the derivatization of glyphosate with $\mathrm{Fmoc}-\mathrm{Cl}$ improved its detection by HPLC-FL. Figure 2 shows the chromatogram of glyphosate in matrix. 


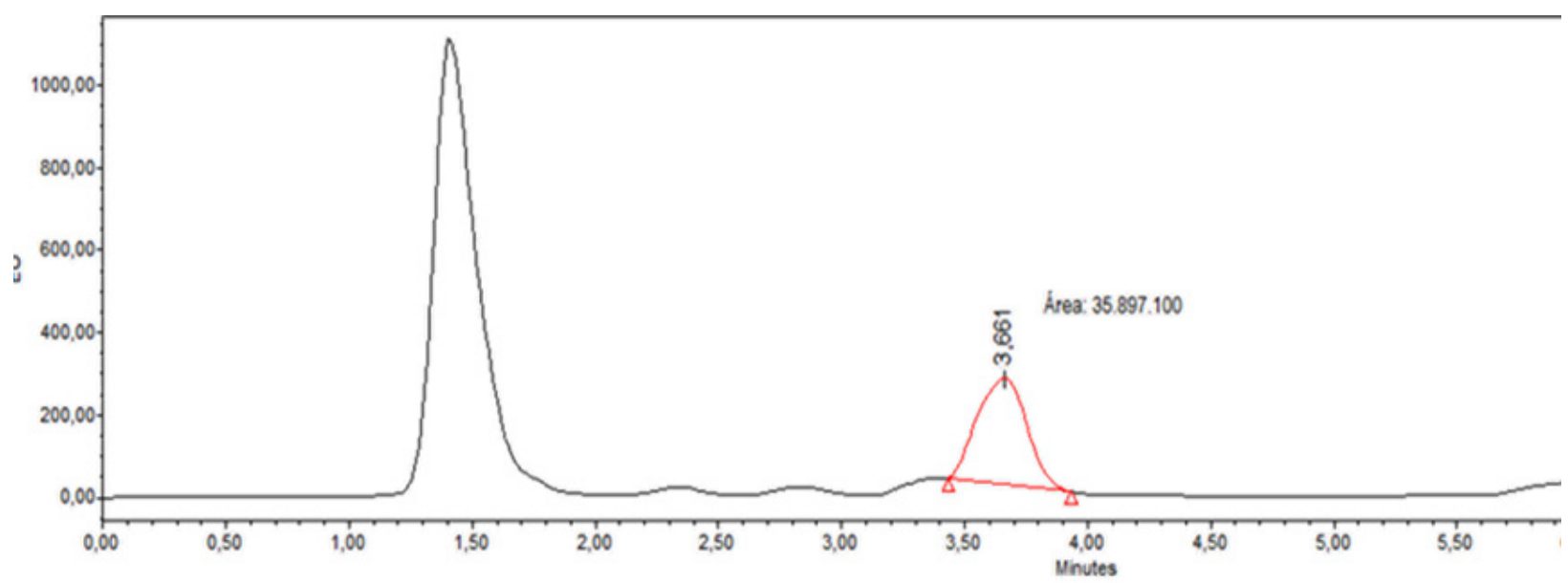

Figure 1. Gramlich et al. 2019

In the evaluation of the matrix effect, no interference of compounds in the retention time of the analyte was observed. During the analysis, no significant loss of signal or increase in the retention time windows of the compound of interest was found.

The repeatability test was performed in matrix at 5 different fortification levels: 5; 10; 50; 70 and 120ng/ $\mathrm{mL}$ six times on the same day and with the same analyst. The intermediate precision evaluated these same levels of concentration six times, but two days after the first evaluation with the same analyst. In both cases, the standard deviation and coefficient of variation (CV) were verified, and they did not present significant statistical difference during the precision analysis.

Recovery rates were calculated and verified if they were in the acceptability range of 70 to $120 \%$. The recovery values were considered satisfactory, presenting good accuracy and precision with coefficients of variation lower than 20\%. Thus, the results are acceptable and within the regulated values, which means the established results are acceptable for the recovery of biological samples in the range of $69.7-86.0 \%$.

The $\mathrm{F}$ test performed in the repeatability test and intermediate precision showed that no statistically significant differences were found between the precisions on different days, since the values were in the range of 1.11 and 2.74, less than the tabulated (5.05). The applicability of the method was verified through the analysis of a fortified matrix with glyphosate at the levels described in Table 2 .

\begin{tabular}{|c|c|c|c|}
\hline Sample & Result (ng/mL) & Sample & Result (ng/mL) \\
\hline $1 \mathrm{HIGH}$ & $<0.34$ & $16 \mathrm{HIGH}$ & $2.57(0.13)$ \\
\hline $2 \mathrm{HIGH}$ & $<0.34$ & $17 \mathrm{HIGH}$ & $<0.34$ \\
\hline $3 \mathrm{HIGH}$ & $<0.34$ & $18 \mathrm{HIGH}$ & $<0.34$ \\
\hline $4 \mathrm{HIGH}$ & $2.87(0.07)$ & $19 \mathrm{HIGH}$ & $7.13(0.52)$ \\
\hline $5 \mathrm{HIGH}$ & $3.09(0.09)$ & $20 \mathrm{HIGH}$ & $<0.34$ \\
\hline $6 \mathrm{HIGH}$ & $1.65(0.10)$ & $21 \mathrm{HIGH}$ & $2.87(0.35)$ \\
\hline $7 \mathrm{HIGH}$ & $2.27(0.22)$ & $22 \mathrm{HIGH}$ & $<0.34$ \\
\hline $6 \mathrm{HIGH}$ & $<0.34$ & $23 \mathrm{HIGH}$ & $<0.34$ \\
\hline $9 \mathrm{HIGH}$ & $<0.34$ & $24 \mathrm{HIGH}$ & $<0.34$ \\
\hline $10 \mathrm{HIGH}$ & $6.41(0.28)$ & $25 \mathrm{HIGH}$ & $4.19(0.38)$ \\
\hline $11 \mathrm{HIGH}$ & $<0.34$ & $26 \mathrm{HIGH}$ & $<0.34$ \\
\hline $12 \mathrm{HIGH}$ & $2.03(0.27)$ & $27 \mathrm{HIGH}$ & $<0.34$ \\
\hline $13 \mathrm{HIGH}$ & $<0.34$ & $28 \mathrm{HIGH}$ & $<0.34$ \\
\hline $14 \mathrm{HIGH}$ & $<0.34$ & $29 \mathrm{HIGH}$ & $<0.34$ \\
\hline $15 \mathrm{HIGH}$ & $4.40(0.22)$ & $30 \mathrm{HIGH}$ & $<0.34$ \\
\hline
\end{tabular}




\section{DISCUSSION}

In the United States, according to regulatory bodies, the Acceptable Daily Intake (ADI) of glyphosate is $1.75 \mathrm{mg} / \mathrm{kg} /$ day [16]. In the European Union, this limit is $0.3 \mathrm{mg} / \mathrm{kg} /$ day [17], while in Brazil, according to ANVISA, an ADI of $0.042 \mathrm{mg} / \mathrm{kg}$ (42ng/mL) [13] was established.

Although glyphosate residues were present in some of the samples analyzed, none of the cases exceeded the values allowed, established at national and international levels, since the highest level found was $7.13 \mathrm{ng} / \mathrm{mL}$. The highest value found in the samples was $0.007 \mathrm{mg} / \mathrm{kg}$. This value represents an external dose of $0.0011 \mathrm{mg} / \mathrm{kg}$ that was determined based on the studies carried out by Niemann [15] and Silbernagel and Despopoulos, 2006 [35]. Regarding the kinetics of glyphosate considered a daily volume of urine of 2 liters for an adult person with average body mass of $60 \mathrm{~kg}$ [35]. However, this assumption presents a great variability, since the excretion may be higher or lower depending on the amount of liquid the person drank and on the excretion by other routes, such as transpiration, which may be significant. In this context, the calculations used to determine the external dose for the highest level of glyphosate found in the urine samples analyzed are described below.

$$
\begin{aligned}
& \text { Internal Dose }\left(\frac{\mu g}{\mathrm{~kg}} \times \text { body mass }\right)=\frac{\text { Curine } x \text { Vurine }}{\text { Body mass }} \\
& \text { Internal Dose }=\frac{7.13 \mu \mathrm{g} / \mathrm{L} \times 2 \mathrm{~L}}{60 \mathrm{~kg}} \\
& \text { Internal Dose }=0.237 \mu \mathrm{g} / \mathrm{kg}(0.000247 \mathrm{mg} / \mathrm{Kg}) \\
& \text { External Dose }\left(\frac{\mu g}{\mathrm{~kg}} \times \text { body mass }\right)=\frac{100 \times \text { internal dose }}{\% \text { oral absorption }} \\
& \text { External Dose }=\frac{100 \% \times 0.237 \mu \mathrm{g} / \mathrm{kg}}{20 \%} \\
& \text { External Dose }=1.188 \mu \mathrm{g} / \mathrm{kg}(0.001188 \mathrm{mg} / \mathrm{kg})
\end{aligned}
$$

The external dose represents the possible dose with which the farmer had direct contact. As already mentioned, the systemic resorption of glyphosate in the intestine is greatly reduced $[15,35]$. Studies published, suggest an absorption rate of about $20 \%$, which indicates that this ingestion may have been up to five times higher than the resulting internal dose [36].

The volunteers chosen for the development of this study, represented by a group of men and women aged between 20 and 50 years, reproduce the real situation of the diversity in the rural work environment. Thus, it is relevant to know the residue values found in the samples to assess the level of exposure of these workers. For the samples classified as Pre and Post, no quantifiable concentration was found by the method [36].

The candidate with the highest level of glyphosate found in the urine had the experience of 1 year and 9 months and worked preparing soil drench. The one with the lowest level of the herbicide found had the same function with an exposure time of 1 year. As for the farmer who had longer experience, 10 years, no level of glyphosate was detected, and his function was applicator. Age also showed no impact on glyphosate exposure. Thus, factors such as experience time in rural activity, function and age did not present any relation with glyphosate levels found in the samples [33] [34].

According to the studies conducted by Acquavella, 2004 [36], who evaluated the biomonitoring in farmers 
and their families, $40 \%$ of the individuals present in the study did not obtain detectable levels in their urines on the day of application. The authors suggested the potential exposure may be limited to individuals who were not present in the immediate area of the mixture or participating in application activities. Several other studies evaluating rural workers showed that their urines had levels of glyphosate detectable by the developed methods [37] [38]. However, in all of them, the concentrations of this pesticide were lower than the limits allowed by the regulatory bodies [38] [39] [40].

The results give an initial idea that the workers are exposed to glyphosate and the direct contact seems to be the main source of exposure. However, a more detailed study is needed to distinguish between different exposure situations, in addition to direct contact. Thus, the analytical method developed fulfills the validation requirements and is suitable for the determination of glyphosate residues in urine.

\section{CONCLUSION}

Numerous factors can influence changes in the individual's health beyond direct contact with the crop protection product. Therefore, assessing the exposure of rural workers to pesticides is still quite complex. Likewise, it is necessary to diagnose possible health events caused by these agents.

The results presented indicate that on the day of glyphosate exposure, detectable levels of this pesticide were found in urine samples, but during the period before and after exposure and no direct contact. These data corroborate international studies in the literature.

Although these levels indicate a low occupational risk, biomonitoring studies such as this need to be expanded to support more scientifically based regulatory actions.

\section{Acknowledgements and collaborators}

The authors of this study thank the Mato Grosso Soybean Producers Association (Aprosoja - MT) for supplying urine samples from rural workers in this region; we also thank all the farmers who participated in the study and; the collaboration of Angelo Z. Trape for the writing and final review of this article.

\section{REFERÊNCIAS}

1. Duke SO, Powles SB. Glyphosate-resistant crops and weed: now and in the future. Ag Bioforum. 2009; 12:346-347. http://dx.doi.org/10.1002/ps.1518
2. Almeida WF, Garcia EG. Exposição dos trabalhadores rurais aos agrotóxicos no Brasil. 1991.

3. Faria NMX, Facchini LA, Fassa AG, Tomasi E. Processo de produção rural e saúde na serra gaúcha: um estudo descritivo. Cad Saúde Pública. 2000; 16(1): 115-128.

4. Pignati WA, Lima FANS, Lara SS, Correa MLM, Barbosa JR, Leão LHC, et al. Distribuição espacial do uso de agrotóxicos no Brasil: uma ferramenta para a Vigilância em Saúde. Cien. Saúde Colet. 2017; 22(10):3281-3293.

5. Vandenberg LN, Colborn T, Hayes TB. Hormônios e produtos químicos desreguladores endócrinos: Efeitos de baixa dose e respostas não monotônicas. Endocr Rev. 2012; 33 (3): 378-455.

6. Brasil. Ministério da Agricultura. Pecuária e Abastecimento (MAPA). Registro de agrotóxicos concedidos em 2015 a 2019 [online]. Disponível em: http://www.agricultura.gov. br/assuntos/insumos-agropecuarios/insumos-agricolas/ agrotoxicos/informacoes-tecnicas . Acesso em: 01 jul. 2019.

7. Dallegrave E, Mantese FDG, Dalsenter PR, Langeloh A. Acute oral toxicity of glyphosate in Wistar rats. Online J Vet Res. 2002; 1:29-36.

8. Cavalli VLLO, Cattani C, Rieg CEH, Pierozani P, Zanatta L, Parisotto EB, et al. Roundup disrups male reproductive funcitons by triggering calciummediated cell death in rat tests and Sertoli cells. Free Radical Biol and Med. 2013; 65:335-346.

9. Séralini G-E, Clair E, Mesnage R. Republished study: long-term toxicity of a Roundup herbicide and a Rounduptolerant genetically modified maize. Environ Sci Eur. 2014; 26(1):14. http://dx.doi.org/10.1186/s12302-014-0014-5

10. Romano RM, Romano MA, Bernardi MM, Furtado PV, Oliveira CA. Prepubertal exposure to commercial formulation of the herbicide Glyphosate alters testosterone levels and testicular morphology. Arch Toxicol. 2010; 84:309317. http://dx.doi.org/10.1007/s00204-009-0494-z

11. Moreira JC, Jacob SC, Peres F, Lima JS, Meyer A, Oliveira-Silva JJ. et al. Avaliação integrada do impacto do uso de agrotóxicos sobre a saúde humana em uma comunidade agrícola de Nova Friburgo. Ciênc Saúde Colet. 2002; 7(2):299-311. 
12. Carvalho $V$, Tura L. A expansão do monocultivo de soja em Santarém e Belterra: injustiça ambiental e ameaça a segurança alimentar. Belém: FASE; 2006.

$\begin{array}{lrrrr}\text { 13. } & \text { Brasil. } & \text { Agência } & \text { de } & \text { Vigilância } \\ \text { Sanitária. } & \text { Nota } & \text { técnica } & n^{\circ} 23 . & 2018 .\end{array}$

14. Benbrook CM. Trends in glyphosate herbicide use in the United States and globally. Sci Eur. 2016; 28(3). $\quad$ http://dx.doi.org/10.1186/s12302-016-0070-0

15. Niemann L, Sieke C, Pfiel R, Solecki R. A critical review of glyphosate findings in human urine samples and comparation with the exposure on operators and consumers. J Verbr Lebensm. 2015; 10: 0312 . http://dx.doi.org/10.1007/s00003-014-0927-3

16. EPA. Environmental Protection Agency. EPA takes next step in review process for herbicide glyphosate, reaffirms no risk to public health. Disponível em: https://www.efsa.europa. eu/en/topics/topic/glyphosate. Acesso em: 01 jul. 2019.

17. EFSA. European Food Safety Authority. Glyphosate. Disponível em: https://www.epa.gov/newsreleases/epa-takesnext-step-review-process-herbicide-glyphosate-reaffirmsno-risk-public-health 30/04/2019 Acesso em: 01 jul. 2019.

18. Bradberry SM, Proudfoot AT, Vale JA. Glyphosate poisoning. Toxicol Rev. 2004; 23:159-167.

19. Figueiredo GM, Trape AZ, Alonzo HA. Exposição a múltiplos agrotóxicos e prováveis efeitos a longo prazo à saúde: estudo transversal em amostra de 370 trabalhadores rurais de Campinas (SP). Rev Bras Med Trab. 2011; 9(1): 1-9.

20. Benachour N, Séralini GE. Glyphosate formulations induce apoptosis and necrosis in human umbilical, embryonic, and placental cells Chem. Res Toxicol. 2009; 22: 97-105. http://dx.doi.org/10.1021/tx800218n

21. Hammond B, Dudek R, Lemen J, Nemeth M. Results of a 13 week safety assurance study with rats fed grain from glyphosate tolerant corn. Food Chem Toxicol. 2004; 42:1003-14. http://dx.doi.org/10.1016/j.fct.2004.02.013

22. Fagan J, Antoniou M, Robinson C. GMO Myths and Truths: An Evidence-Based Examination of the Claims Made for the Safety and Efficacy of Genetically Modified Crops and Foods. Earth Open Source. 2014:102-121.
23. Meyer $\mathrm{H}$, Hilbeck A. Rat feeding studies with genetically modifiedmaize-acomparativeevaluation ofappliedmethods and risk assessment standards. Environ Sci Eur. 2013;25(33).

24. Thongprakaisang S, Thiantanawat A, Rangkadilok N, Suriyo T, Satayavivad J. Glyphosate induces human breast cancer cells growth via estrogen receptors. Food Chem Toxicol.2013; 59:129136. http://dx.doi.org/10.1016/j.fct.2013.05.057

25. Mesnage R, Bernay B, Seralini GE. Ethoxylated adjuvants of glyphosate-based herbicides are active principles of human cell toxicity. Toxicology. 2013; 313(2013):122$128 . \quad \mathrm{http}: / / \mathrm{dx}$.doi.org/10.1016/j.tox.2012.09.006

26. Antoniou M, Habib MEM, Howard CV. Teratogenic effects of glyphosate-based herbicides: Divergence of regulatory decisions from scientific evidence. J Env Anal Toxicol. 2012. http://dx.doi.org/10.4172/2157-7439.1000379

27. Benedetti $A L$, Vituri $C L$, Trentin $A G$, Domingues MA, Alvarez-Silva $M$. The effects of sub-chronic exposure of Wistar rats to the herbicide GlyphosateBiocarb. Toxicol Lett. 2004; 153(2): 227-32. http://dx.doi.org/10.1016/j.toxlet.2004.04.008

28. Lee $\mathrm{HL}$, Kan $C D$, Tsai $C L$, Liou MJ, Guo HR. Comparative effects of the formulation of glyphosate-surfactant herbicides on hemodynamics in swine. Clin Toxicol Phila Pa. 2009; 47(7):651-658.

29. Adam A, Marzuki A, Abdul Rahman, H. Abdul Aziz, M. The oral and intratracheal toxicities of ROUNDUP and its components to rats. Vet Hum Toxicol. 1997; 39(3):147-151. 1997.

30. Brasil. Agência Nacional de Vigilância Sanitária (ANVISA). Legislação. Visa Legis. Resolução RE n¹19, de 2010. Determina a publicação do "Programa de Análise de Resíduos de Agrotóxicos em Alimentos". 2010.

31. Pignati W, Oliveira NP, Silva AMC. Vigilância aos agrotóxicos: quantificação do uso e previsão de impactos na saúde-trabalho-ambiente para os municípios brasileiros. Cien Saude Colet. 2014; 19(12):4669-4678.

32. Brasil. Instituto Brasileiro de Geografia e Estatística (IBGE). Sistema IBGE de Recuperação Automática. Produção Agrícola Municipal. Brasília, Distrito 
federal; 2014. Disponível em: https:// sidra.ibge. gov.br/home/ipp/brasil. Acessado em: 02 jul. 2019.

33. Oliveira-Silva JJ, Alves SR, Meyer A, Perez F, Sarcinelli PN, Mattos RCO, et al. Influência de fatores socioeconômicos na contaminação por agrotóxicos. Rev Saude Publica. 2001; 35(2):130-5.

34. Sam KG, Andrade HH, Pradhan L, Pradhan A, Sones SJ, Rao PG, et al. Effectiveness of an educational program to promote pesticide safety among pesticide handlers of South India. Int Arch Occup Environ Health. 2008; 81(6):787-95.

35. Silbernagel $S$, Despopoulos A. Taschenatlas der Physiologie. Anatomie und Physiologie. Wiley-VCH, Weinheim; 2006.

36. Acquavella JF, Bleeke M, Gustin C, Alexander BH, Baker $B$, Mandel JS, et al. Glyphosate biomonitoring for farms and theis families: results from the farm family exposure study. 2004; 112: 321-326. http://dx.doi.org/10.1289/ehp.6667

37. Curwin BD, Hein MJ, Sanderson WT, Striley C, Heederick $D$, Kromhout $H$, et al. Urinary pesticide concentrations among children, mothers and fathers living in farm and non-farm households in iowa. Ann Occup Hyg. 2007; 51(1):53-65. http://dx.doi.org/10.1093/annhyg/mel062

38. Hoppe HW, Schledorn P, Kruger M, Schrodl W, Lutz $W$, et al. Detection of Glyphosate Residues in Animals and Humans. J Environ Anal Toxicol. 2014; 4: 1-5. http://dx.doi.org/10.4172/2161-0525.1000210

39. Roca M, Yusà V, Leon N, Pastor A. Comprehensive analytical strategy for biomonitoring of pesticides in urine by liquid chromatography-orbitrap high resolution mass spectrometry. J Chromatography. 2014; 1374: 6676. http://dx.doi.org/10.1016/j.chroma.2014.11.010.

40. Zouaoui K, Dulaurent S, Gaulier JM, Moesch C, Lachâtre G. Determination of glyphosate and AMPA in blood and urine from humans: about 13 cases of acute intoxication. J Forense Sci. 2013; 226: 2025. http://dx.doi.org/10.1016/j.forsciint.2012.12.010 